Rolek, B. W., G. Schrott, D. Z. Poulton, and R. Bowman. 2016. Risk from cattle trampling to nests of an endangered passerine evaluated using artificial nest experiments and simulations. Avian Conservation and Ecology 11(1):6. http://dx.doi.org/10.5751/ACE-00838-110106

Copyright (C) 2016 by the author(s). Published here under license by the Resilience Alliance.

Research Paper

\title{
Risk from cattle trampling to nests of an endangered passerine evaluated using artificial nest experiments and simulations
}

\author{
Brian W. Rolek ${ }^{1,2}$, Gregory Schrott ${ }^{1}$, D. Zak Poulton ${ }^{1}$ and Reed Bowman ${ }^{1}$ \\ ${ }^{1}$ Avian Ecology Laboratory, Archbold Biological Station, ${ }^{2}$ Department of Wildlife, Fisheries, and Conservation Biology, University \\ of Maine
}

\begin{abstract}
Grasslands are often grazed by cattle and many grassland birds nest on the ground, potentially exposing nests to trampling. We tested for trampling risk introduced by cattle to nests of endangered Florida Grasshopper Sparrows (Ammodramus savannarum floridanus) using experimentally paired grids of artificial nests (i.e., clay targets) similar in size to nests of Florida Grasshopper Sparrows and counted the number of clay targets that were broken in paired grazed and ungrazed enclosures. Clay targets in grazed grids were trampled 3.9\% more often than their respective ungrazed grids, and measurements of cattle presence or density were correlated with the number of broken clay targets, suggesting that excluding cattle during breeding is an important management recommendation for the Florida Grasshopper Sparrow. Trampling rates within grazed enclosures were spatially homogeneous with respect to cattle infrastructure such as supplemental feeding troughs and fences, and forests and stocking density were poor predictors of trampling rates when excluding ungrazed grids. We used population viability analysis to compare quasi-extinction rates, intrinsic growth rates, and median abundance in grazed and ungrazed Florida Grasshopper Sparrow aggregations to further understand the biological significance of management aimed at reducing trampling rates during the breeding season. Simulations indicated that trampling from grazing increased quasi-extinction rates by $41 \%$ while reducing intrinsic growth rates by 0.048 , and reducing median abundance by an average of 214 singing males after 50 years. Management should avoid grazing enclosures occupied by Florida Grasshopper Sparrows during the nesting season to minimize trampling rates. Our methods that combine trampling experiments with population viability analysis provide a framework for testing effects from trampling on other grassland ground-nesting birds, and can directly inform conservation and management of the Florida Grasshopper Sparrow.
\end{abstract}

\section{Évaluation du risque de piétinement par le bétail de nids de passereaux menacés à partir d'expériences avec des nids artificiels et de simulations}

RÉSUMÉ. Les prairies sont souvent broutées par le bétail et de nombreux oiseaux de prairie nichent au sol, exposant ainsi potentiellement leur nid au piétinement. Nous avons testé le risque de piétinement causé par le bétail des nids du Bruant sauterelle de Floride (Ammodramus savannarum floridanus), une espèce menacée, au moyen de grilles expérimentales appariées de nids artificiels (c.à-d. disques d'argile), semblables en taille aux nids des Bruants sauterelles de Floride. Nous avons compté le nombre de disques d'argile qui ont été détruits dans les enclos appariés broutés ou non broutés. Les disques d'argile situés dans les grilles broutées ont été piétinés $3,9 \%$ plus souvent que ceux qui sont sis dans les grilles non broutées appariées, et les mesures de la présence du bétail ou de la densité étaient corrélées avec le nombre de disques détruits; ces résultats nous mènent à recommander fortement l'exclusion du bétail durant la nidification du Bruant sauterelle de Floride. Le taux de piétinement dans les enclos broutés était homogène spatialement relativement aux infrastructures pour le bétail telles que les auges et les clôtures, et la distance à la forêt et la densité du bétail se sont avérées de mauvaises variables prédictives du taux de piétinement lorsque les grilles non broutées étaient exclues. Nous avons utilisé des analyses de viabilité des populations pour comparer le taux de quasi-extinction, le taux de croissance intrinsèque et l'abondance médiane des regroupements de Bruants sauterelles de Floride en milieu brouté ou non brouté afin de mieux comprendre la contribution biologique de l'aménagement visant à réduire le taux de piétinement durant la saison de nidification. Des simulations ont montré que le piétinement attribuable au broutement augmente le taux de quasi-extinction de $41 \%$, réduit le taux de croissance intrinsèque de 0,048 et réduit l'abondance médiane de 214 mâles chanteurs après 50 ans en moyenne. Le broutement devrait être évité dans les enclos occupés par le Bruant sauterelle de Floride durant la saison de nidification afin de minimiser le taux de piétinement. En combinant des expériences de piétinement et des analyses de viabilité des populations, nos méthodes fournissent un cadre pour tester les effets du piétinement sur d'autres oiseaux de prairie nichant au sol et peuvent guider directement la conservation et l'aménagement de l'habitat du Bruant sauterelle de Floride.

Key Words: biological significance; Florida dry prairie; Florida Grasshopper Sparrow; grassland birds; grazing cattle; ground-nesting birds; population viability analysis; simulations 


\section{INTRODUCTION}

Grassland bird populations are declining disproportionately compared with other North American avifauna (Peterjohn and Sauer 1999), enough to warrant warnings of a conservation crisis (Brennan and Kuvlesky 2005). In some cases, even relatively large patches of remnant grasslands may not be adequate to prevent population declines of birds dependent on this habitat (With et al. 2008). Careful management of remaining habitat, public or private, may be essential for successful conservation efforts especially for endangered species.

The Florida Grasshopper Sparrow (Ammodramus savannarum floridanus) is one of the most endangered birds in the continental United States. This bird is a nonmigratory subspecies of Grasshopper Sparrow endemic to the dry prairie of south-central Florida (Pranty and Tucker 2006) and has been federally listed as endangered since 1986 (U.S. Fish and Wildlife Service 1986). The sparrow inhabits three patches of publicly owned land: Three Lakes Wildlife Management Area, Kissimmee Prairie Preserve State Park, and Avon Park Air Force Range. The population at Avon Park Air Force Range was at one time the largest monitored but has experienced an estimated 99\% decline since 1997 (Tucker et al. 2010a), and by 2012, the population was nearly extirpated. Populations at Kissimmee Prairie Preserve State Park have also declined (Tucker et al. 2010a) but only more recently. Causes of these declines are poorly understood, but two of the three extant populations are now too small to quantitatively assess the impacts of most management practices on Florida Grasshopper Sparrow demography. The historic decline of the Florida Grasshopper Sparrow is primarily the result of habitat loss as the amount of dry prairie has been reduced by $80 \%-90 \%$ from its original extent (Shriver and Vickery 1999, Delany et al. 2007, Noss 2013).

Grazing on public lands remains a contentious issue for conservationists, agriculturalists, and government agencies. The U.S. Bureau of Land Management alone manages 245 million acres of land, of which 155 million acres are leased for grazing, which provided more than $\$ 12$ million in fees in 2014 (U.S. Department of Interior 2015). Furthermore, cattle production in the United States on both private and public land was valued at tens of billions of dollars in 2014(U.S. Department of Agriculture 2015). The economic and conservation implications of managing with grazing are large.

In south-central Florida, cattle ranches are of cultural significance and have played a large role in land use and conversion. Much of Florida dry prairie habitat has been converted to pastures of nonnative grasses that do not appear to support large populations of Florida Grasshopper Sparrows (Delany et al. 2007). Most conversion has occurred since the 1950s, although the practice dates to the mid-1920s (Rummell 1957). Remnant patches of dry prairie occur on cattle ranches, and small populations of Florida Grasshopper Sparrow exist on some of these private lands. Appropriate management on both private and public grazed lands could play an essential role in the recovery of this subspecies (Perkins et al. 2008).

One notable difference between management at Avon Park Air Force Range and other publicly owned sites was the continued grazing of cattle on dry prairie. The dry prairie at Avon Park Air Force Range had been grazed at least since the 19th century by cattle ranchers (B. Tortelli, Geo-Marine, unpublished report), although grazing practices have varied over time and grazing of these prairies ended in 2013. Kissimmee Prairie Preserve State Park and Three Lakes Wildlife Management Area also formerly allowed grazing by cattle. However, grazing was discontinued in most Florida Grasshopper Sparrow habitat in the mid-1980s at Kissimmee Prairie Preserve State Park and in 1987 at Three Lakes Wildlife Management Area (Perkins et al. 2009), although some land remains under lease at Kissimmee Prairie Preserve State Park. The direct effects from grazing cattle on Florida Grasshopper Sparrows are poorly understood, partly because the Florida Grasshopper Sparrow population on Avon Park Air Force Range, the most recently grazed site, has been too small, making statistically robust inference impossible. Despite intensive monitoring of Florida Grasshopper Sparrows at Avon Park Air Force Range, we found no active nests during the period of study, and $\leq 4$ singing males were observed each year, preventing any study on the effects of trampling with real nests.

The documented effects from grazing on nesting of other subspecies of Grasshopper Sparrow have mostly been negative and include the destruction of nests by cattle from trampling (Renfrew et al. 2005), mortality of fledglings from trampling (Hovick et al. 2011), reduced clutch sizes and nest success (Sutter and Ritchison 2005, Rahmig et al. 2009), reduced prey biomass, and higher overall predation rates (Sutter and Ritchison 2005). Grazing, its effects on vegetation, and associated infrastructure are thought to have several other indirect negative effects on Florida Grasshopper Sparrow (e.g., Tschinkel 1988, Tschinkel 1993, Allen et al. 1994, Pranty 2000, Nack and Ribic 2005, Rader et al. 2007, Tucker et al. 2010b). Several studies have shown preference by other subspecies of Grasshopper Sparrow for habitats that are more intensively grazed (e.g., Kantrud and Kologiski 1982, Griebel et al. 1998, Hovick et al. 2012); however, preference for less intensively grazed habitat has also been demonstrated (Bock et al. 1984, Bock and Webb 1984). Preference for grazed versus ungrazed habitat may vary depending on the habitat type and geography. At least one study has shown that grazed areas can become ecological traps (Shochat et al. 2005) where preferred habitat results in reduced fitness. Research on other subspecies of Grasshopper Sparrow and other groundnesting birds suggests that grazing cattle can negatively influence populations in various ways, including trampling nests (Beintema and Muskens 1987, Green 1988, Liker and Székely 1997, Pavel 2004, Renfrew et al. 2005, Pakanen et al. 2011).

We sought to experimentally test the influence of trampling rates on artificial nests in prairies that supported populations of the ground-nesting Florida Grasshopper Sparrow and that were grazed by cattle. Our objectives were to use artificial nests to (1) experimentally test the risks of cattle trampling on ground-nesting grassland birds and Florida Grasshopper Sparrow nests; (2) assess the spatial influence of grazing infrastructure, such as fencing or feeding troughs, or environmental factors such as forests that could influence the distribution of cattle and therefore trampling rates within enclosures; (3) estimate the potential influence of grazing management on population persistence of Florida Grasshopper Sparrow using simulations; and (4) suggest management that may minimize trampling damage to nests of Florida Grasshopper Sparrows and other ground-nesting birds. 


\section{METHODS}

\section{Study site}

Our research was conducted at Avon Park Air Force Range, a 42,897-ha facility located in Polk and Highlands Counties, Florida. Land uses include military training, consumptive resource extraction, recreation, and conservation. Dry prairie at Avon Park Air Force Range occurs in a larger landscape of native and altered habitats including freshwater marshes, pine flatwoods, pine plantations, oak hammocks, and oak-dominated scrub. Avon Park Air Force Range has been leased for grazing since at least 1984 (Perkins et al. 2009), but grazing has occurred over a much longer time span and free-ranging cattle formerly occurred throughout the region following their introduction to Florida by Ponce de Leon in 1521 (Rummell 1957). More recently, much of the dry prairie at Avon Park Air Force Range has been rotationally grazed. Each grazing unit, i.e., an area leased to a cattle rancher, was composed of between two and five enclosures. Cattle within units were rotated among enclosures and the length of each rotation ranged from several weeks to several months.

\section{Sampling design}

Previous studies have used simulated nests to quantify the effects of trampling on breeding birds (Henry 1969, Bareiss et al. 1986), using clay pigeon shooting targets (herein clay targets, e.g., Koerth et al. 1983, Jensen et al. 1990; Fig. 1). Clay targets are fragile like eggs (Paine et al. 1997) and can provide evidence of trampling while excluding the effects of nest predation from nest success estimates (Jensen et al. 1990, Koerth et al. 1983). Rates of trampling by cattle appear to be similar between clay target nests and simulated nests with real eggs ( $35 \%$ vs. $36 \%)$, demonstrating that the use of clay targets can provide a reasonable measure of nest trampling rates by cattle; however, rates of disturbance were larger using clay targets (Paine et al. 1997). Because of the logistical constraints of working on an active bombing range with unexploded ordinance, we were restricted to using artificial nests in the form of clay targets.

To quantify the potential risk to nests of Florida Grasshopper Sparrows from trampling by grazing cattle, we used 108-mm nontoxic biodegradeable clay targets produced by White Flyer Division Reagent Chemical and Research Inc. (Ringoes, New Jersey, USA) that are similar in size to actual Florida Grasshopper Sparrow nests. The size of our clay targets reasonably represent the probability of a nest being trampled for Florida Grasshopper Sparrows because the outer diameter of each clay target is within the range of outer nest diameters reported by Vickery (1996; range $=10.8-13.3 \mathrm{~cm})$ and Delany and Linda $(1998$; mean $=10.3 \mathrm{~cm}$, range $=8.8-12.3 \mathrm{~cm})$. We placed clay targets in remnant Florida dry prairie habitat (Bridges 2006) within the time period of previously documented nest dates of Florida Grasshopper Sparrow (mid-March to late-August; McNair 1986, Perkins et al. 2003). Rotational grazing provided spatially and temporally similar plots that enabled us to place at least one grid per grazing treatment in two adjacent enclosures where one enclosure was grazed and one enclosure was not grazed. Herein, we refer to "grazed" enclosures where cattle grazed while clay target grids were present, and "ungrazed" enclosures where cattle were not present while the clay target grid was deployed. All enclosures used in this study were grazed for some period while clay targets were deployed because enclosures were rotationally grazed.
Fig. 1. Cattle trampling clay pigeons. This is a staged photo in nonnative pasture adjacent to dry prairie.

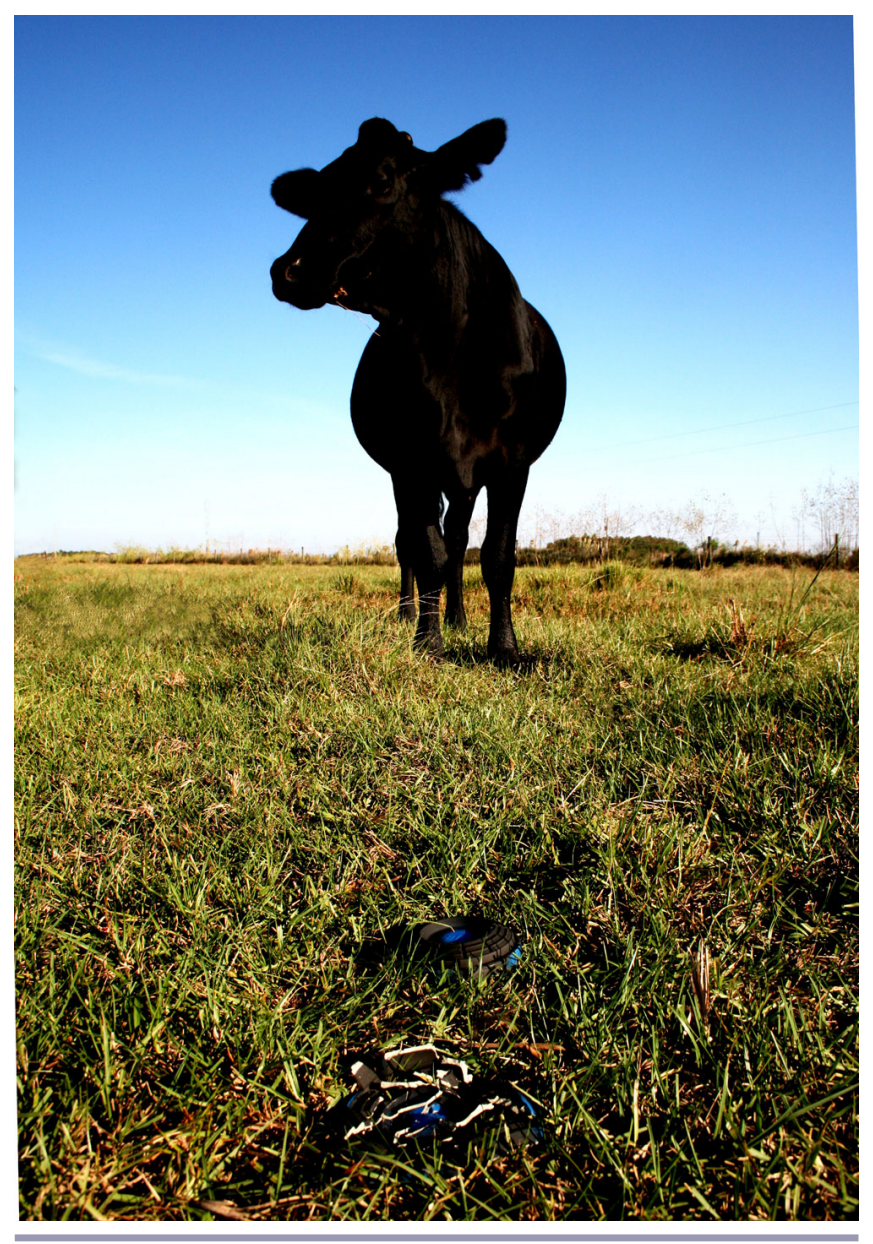

We created 105 x 40-m grids of 5 by 21 clay targets (totaling 105 clay targets) containing 5 rows spaced $10 \mathrm{~m}$ apart; within rows clay pigeons were spaced $5 \mathrm{~m}$ apart. All clay target grids within the same enclosure were placed more than $100 \mathrm{~m}$ apart. We placed grids at varying distances to forests, wetlands, and roads. We created experimentally paired grids by separating them on opposite sides of fences. This sampling design covered nearly all available Florida Grasshopper Sparrow habitat at Avon Park Air Force Range where we could compare paired grids in adjacent enclosures. We deployed some grids in grazed habitat that were not paired with grids in adjacent ungrazed areas to increase sample sizes for analyses on the effects of proximity to infrastructure associated with grazing (e.g., feeding troughs). We omitted these grids from experimentally paired analyses. Other species that occupy dry prairie such as white-tailed deer (Odocoileus virginianus) and feral hogs (Sus scrofa) could trample bird nests and clay targets. We controlled for this possibility by sampling grids in ungrazed habitat to measure background rates of trampling caused by sources other than cattle. We left clay targets in the field for 22 days, approximately the same length of time that it takes for Florida Grasshopper Sparrows to lay eggs, incubate, hatch, and fledge chicks (Vickery 1996). After the 22nd day, we counted the number of clay targets that were undisturbed, 
Table 1. Continuous variables that were tested in analyses, their mean, standard deviation (SD), range, and unit of measure.

\begin{tabular}{lcccc}
\hline \hline Variable & Mean & SD & Range & Unit \\
\hline Cattle counted & 5.49 & 10.51 & 0 to 47.8 & Individuals \\
Stocking density & 0.18 & 0.27 & 0 to 0.99 & Animal units per hectare \\
Distance to trough & 1.52 & 0.77 & 0.03 to 3.49 & Kilometer \\
Distance to fence & 0.19 & 0.16 & 0.01 to 0.61 & Kilometer \\
Distance to forest & 0.31 & 0.24 & 0.01 to 1.13 & Kilometer \\
\hline
\end{tabular}

disturbed (i.e., moved from transect, flipped, missing, or altered but not broken), or broken. We considered the number of clay targets that remained present (i.e., undisturbed plus broken) as the offset for each grid in the statistical analyses below. We collected and removed all clay targets and their fragments.

We placed clay targets in Florida dry prairie that contained grasses and grass-like monocots, along with saw palmetto (Serenoa repens) and/or dwarf live oak (Quercus minima), similar to microhabitats documented at locations of Florida Grasshopper Sparrow nests (Delany and Linda 1998). We did not place clay targets in cattle trails, which are preferentially used by cattle, and we also avoided wetlands where Florida Grasshopper Sparrows are less likely to nest. Grazing did not always adhere to precisely timed rotations; therefore, we deployed grids only after we observed cattle being introduced or removed from an enclosure. We used some grid locations twice, before and after cattle were rotated to the adjacent enclosure, thus changing the status of both adjacent grids and enclosures but maintaining the spatial locations of grids.

We obtained data on the number of animal units in each grazing unit from AP's Environmental Flight staff, although these figures were acknowledged to be estimates, and used them to calculate stocking densities. We measured the area of each enclosure with ArcMap 10.0 (ESRI, Redlands, California, USA) and calculated stocking density as $s=u / a$, where $s$ is the stocking density expressed in animal units per hectare, $u$ is the number of animal units reported in an enclosure, and $a$ is the area of an enclosure in hectares. One animal unit per hectare approximates one 386$\mathrm{kg}$ cow and calf pair. However, stocking density assumes a cowcalf pair and not all cows have calves (for further discussion, see Jensen et al. 1990). In addition, grazing densities and rotations were not consistently defined or followed; therefore, we conducted cattle counts.

While grids were deployed, we scanned plots with binoculars on days $1,6,12,18$, and 22 to count the number of cattle within enclosures. We allowed one day before or after days 6, 12, and 18 to conduct our counts to work around military training missions that occasionally restricted access to study sites. We calculated the average number of cattle counted per survey for each grid. We counted cattle as total number of individuals, including both adults and calves. Cattle counts provided a measure of cattle activity at each site in the event that ranchers changed grazing locations without notification.

We measured minimum distance from each grid to nearest supplemental mineral trough, fence, forest edge, and pond or wetland edge within each enclosure for each grazed grid by using aerial photographs, the Global Positioning System, and ArcMap
(Table 1). Cattle congregate around troughs (Usman 1994), and higher trampling rates occur near wetlands (reviewed by Bailey et al. 1996), whereas forest patches provide shade and cattle may walk the perimeters of fences. We only considered features that were within the same fenced enclosure as the clay target grid that were accessible to cattle.

\section{Statistical analyses}

\section{Grazing and cattle density}

We compared the number of broken clay targets within experimental pairs of grazed versus ungrazed grids using a onetailed paired $t$-test. We considered each paired grid as a sample.

We combined all grids for which we collected data, many of which were not used in paired comparisons because both grids were either grazed or not grazed, thus not meeting our experimental criterion. We tested for associations with rates of broken clay targets using generalized linear models with negative binomial distributions implemented using the aod package (Lesnoff and Lancelot 2012) to avoid overdispersion because we observed a large number of zeroes for the response variable. We tested the models for overdispersion using a Pearson's $\mathrm{X}^{2}$ divided by the residual degrees of freedom implemented using the $\mathrm{R}$ package AICcmodavg. The negative binomial model had acceptable overdispersion $(\mathrm{c}-\mathrm{hat}=1.15)$. Models were determined a priori (Table 2) to test whether the number of clay targets broken was a function of the number of cattle counted, the stocking density, or a categorical variable of grazing status, i.e., grazed or ungrazed. These models followed this general structure:

$$
\mu_{i}=\exp \left(\alpha+\beta x_{i}+\log \left(z_{i}\right)\right)
$$

where $\mu$ is the number of broken clay targets, $\alpha$ is the intercept, $\beta$ is the parameter estimate for covariate $x$ at grid $i$, and $z$ is the number of present clay targets for each grid (described above). The exposure portion of the model allows estimation and modeling of rates of broken clay targets, $\mu_{\mathrm{i}} / z_{\mathrm{i}}$. We did not include more than one covariate in each model to avoid collinearity because each variable describes similar phenomena and variables were expected to be highly correlated, which would violate assumptions of this regression method.

\section{Infrastructure}

To test whether the rate of broken clay targets within each grid was influenced by grazing infrastructure and landscape characteristics, we examined a subset of data from enclosures that were determined to be grazed, because ungrazed grids are not expected to be influenced by trampling. We used a generalized linear model with a Poisson distribution and included distance to fence, forest, or trough as covariates. We included variables as 
Table 2. Model comparison for the proportion of clay targets broken within each sample grid at Avon Park Air Force Range, Florida, to test whether grazing influences proportion of nests trampled. Infrastructure analysis used data from grazed enclosures to test effects on proportion of clay targets broken. "Null" indicates that no covariates were included for that model; AIC is Akaike's information criterion corrected for small sample size; $w$ is Akaike weight for model $i$; and $\mathrm{k}$ is the number of parameters included in each model. Covariates for infrastructure models are nearest distance in kilometers from that object to the grid.

\begin{tabular}{|c|c|c|c|c|c|c|}
\hline Analysis & Model & $\mathrm{k}$ & $\mathrm{AIC}_{\mathrm{c}}$ & $\Delta \mathrm{AIC}_{\mathrm{c}}$ & $w_{i}$ & Log-likelihood \\
\hline \multirow[t]{4}{*}{ Cattle } & Cattle counts & 3 & 342.62 & - & - & -168.13 \\
\hline & Grazed or ungrazed & 3 & 357.82 & 0.00 & 0.70 & -175.73 \\
\hline & Stocking & 3 & 360.17 & 2.35 & 0.22 & -176.90 \\
\hline & Null & 2 & 362.17 & 4.35 & 0.08 & -179.00 \\
\hline \multirow[t]{2}{*}{ Infrastructure } & Trough & 3 & 250.82 & 0.00 & 0.59 & -122.11 \\
\hline & Null & 2 & 251.57 & 0.75 & 0.41 & -123.64 \\
\hline
\end{tabular}

additive covariates. Poisson models were overdispersed $(\mathrm{c}-\mathrm{hat}=$ 7.48), which indicated they were inappropriate for analyzing the data, so we used negative binomial distributions instead. We included an offset as described above (equation 1). Although wetlands are attractive to cattle (Bailey et al. 1996), we did not test for an association between trampling rates and wetlands to avoid collinearity because distance to wetland was moderately correlated with distance to trough (Pearson's product moment correlation, $\beta=0.385,95 \%$ confidence intervals $=0.10$ and 0.61 ). We chose to analyze distance to trough instead because troughs are more practicable management targets than wetlands. We centered and standardized the variables distance to trough, fence, and forest prior to including them as covariates in models so that the magnitude of effects could be directly compared (Nakagawa and Cuthill 2007). We converted standardized values back to the scale of the original data for plotting and interpretation of model results.

For all regression analyses, we compared models using Akaike's information criterion corrected for small sample size $\left(\mathrm{AIC}_{\mathrm{c}}\right)$, because Burnham and Anderson (2002) recommend $\mathrm{AIC}_{\mathrm{c}}$ when the ratio of the number of samples to the number of parameters is less than 40 . We considered models to have substantial support when $\Delta \mathrm{AIC}_{\mathrm{c}}<2$; considerably less support when $\triangle \mathrm{AIC}_{\mathrm{c}}$ is between 4 and 7; and essentially no support when $\Delta \mathrm{AIC}_{\mathrm{c}}$ is greater than 10. We considered a covariate significant when it had substantial model support $\left(\triangle \mathrm{AIC}_{\mathrm{c}}<2\right.$; Burnham and Anderson 2002) and $90 \%$ confidence intervals did not include zero. We also present $95 \%$ confidence intervals for comparison. We used $90 \%$ confidence intervals because of the endangered status of the Florida Grasshopper Sparrow and caution that is warranted with management strategies. We assessed whether parameters were uninformative by comparing each $\mathrm{AIC}_{\mathrm{c}}$ value to a similar model lacking that variable. A variable was considered uninformative if the additional variable did not reduce parsimony by at least 2.0 $\mathrm{AIC}_{\mathrm{c}}$ (Burnham and Anderson 2002, Arnold 2010). For models sets where no stand-alone model was substantially supported (i. e, $\Delta \mathrm{AIC}_{\mathrm{c}}<2.0$ from the second-most parsimonious model), we used model averaging to obtain estimates and confidence intervals to account for model selection uncertainty (Burnham and Anderson 2002). We used R statistical software version 3.0.2 (R Development Core Team 2013, Vienna, Austria, http://www.Rproject.org) for all analyses.
We present estimates obtained from model outputs as proportion of clay targets trampled for ease of interpretation and to emphasize that we are interested in comparing relative rates of trampling rather than the actual number of targets trampled to generalize the inference of our study. Clay targets are placed at artificially high densities compared with actual nests, but this should not affect our results because the proportion of clay targets trampled should not change as artificial nest densities increase or decrease. For example, if we sampled the entire enclosure with clay targets, we would expect mean estimates of the proportion of clay targets trampled that were statistically similar to those derived from a random sample. Moreover, trampling risk was not affected by nest densities in similar studies (Koerth et al. 1983, Beintema and Muskens 1987).

\section{Simulations}

We used population viability analysis to compare the relative effects from managing Florida Grasshopper Sparrows by adding or removing grazing. We created a demographic stage-structured model with two age classes, juveniles and adults, to simulate population dynamics and assumed a stable age distribution (Perkins et al. 2008). All population parameters were extracted from Perkins and Vickery 2001, Perkins et al 2003, and Perkins et al. 2008. Initial populations represented males because they are well surveyed using the point count methodology that is currently used and we assumed an equal sex ratio (Perkins et al. 2008). We included grazing as a nonstochastic state variable by subtracting the estimated effect of trampling from nest success estimates published by Perkins et al. 2003. Site-specific stochastic vital rates included nest success (Table 2 in Perkins et al 2003; Table 1 in Perkins et al. 2008), juvenile survival, and adult survival (Perkins and Vickery 2001; , Table 1 in Perkins et al. 2008). Nonstochastic variables included number of nest attempts per season and sitespecific clutch size (Perkins et al. 2003). Variables are summarized in Appendix 1. We estimated fecundity following Perkins et al. (2008:169) as "the average number of offspring per individual male that survive to breed the following summer, given by the product of productivity (divided by two because male-based fecundity) and survival for either juveniles or adults." We simulated 50,000 iterations over 50 years (Morris and Doak 2002) implemented in $\mathrm{R}$ for both ungrazed and grazed scenarios $(100,000$ simulations total for each site and initial population size). We repeated each simulation for sites Bravo (carrying capacity herein $K, K=30)$, Cutrale $(K=78)$, DeltaOQ $(K=109)$, 
Table 3. Parameter estimates $(\beta)$ for the proportion of clay targets broken along with $90 \%$ and $95 \%$ lower (LCI) and upper confidence (UCI) intervals.

\begin{tabular}{|c|c|c|c|c|c|c|c|}
\hline Model set & Model & Parameter & $\beta$ & $90 \% \mathrm{LCI}$ & $90 \%$ UCI & $95 \% \mathrm{LCI}$ & $95 \%$ UCI \\
\hline \multirow[t]{7}{*}{ Cattle } & \multirow[t]{2}{*}{ Cattle counts } & Intercept & -3.73 & -4.01 & -3.45 & -4.06 & -3.39 \\
\hline & & Cattle counts & 0.06 & 0.03 & 0.08 & 0.03 & 0.09 \\
\hline & \multirow[t]{2}{*}{ Grazed or ungrazed } & Intercept & -3.82 & -4.27 & -3.36 & -4.36 & -3.27 \\
\hline & & Grazed $=1$ & 0.93 & 0.37 & 1.50 & 0.26 & 1.61 \\
\hline & \multirow[t]{2}{*}{ Stocking density } & Intercept & -3.53 & -3.92 & -3.14 & -3.99 & -3.06 \\
\hline & & Stocking density & 1.72 & 0.29 & 3.15 & 0.01 & 3.42 \\
\hline & Null & Intercept & -3.15 & $-3.14^{\dagger}$ & $-2.87 \dagger$ & -3.48 & -2.81 \\
\hline \multirow[t]{5}{*}{ Infrastructure } & \multirow[t]{2}{*}{ Trough } & Intercept & -2.93 & -3.22 & -2.64 & -2.65 & -3.34 \\
\hline & & Trough & -0.289 & -0.560 & -0.018 & -0.611 & 0.033 \\
\hline & Null & Intercept & -2.89 & -3.43 & -2.87 & -3.24 & -2.53 \\
\hline & \multirow[t]{2}{*}{ Model averaged } & Intercept & -2.91 & -3.21 & -2.61 & -3.26 & -2.56 \\
\hline & & Trough & -0.17 & -0.48 & 0.14 & -0.54 & 0.20 \\
\hline
\end{tabular}

${ }^{\dagger}$ Erratum: In the original publication of Table 3 two values were incorrect. They were corrected on 30 June 2016.

Echo $(\mathrm{K}=303)$, Three Lakes Wildlife Management Area $(\mathrm{K}=$ 1250), and Kissimmee Prairie Preserve State Park ( $\mathrm{K}=1852$; Perkins et al. 2008). We varied initial population sizes by $10 \%$, $25 \%, 50 \%, 75 \%, 90 \%$, and $100 \%$ of carrying capacity at each site. We assumed no immigration between sites. We used a ceiling model and assumed a population would be extirpated if it decreased below four singing males to simulate Allee effects (Perkins et al 2008). We compared intrinsic growth rates, quasiextinction probabilities, and median population size at 50 future time steps to assess whether management of grazing influenced the viability of Florida Grasshopper Sparrow populations (Morris and Doak 2002).

\section{RESULTS}

We deployed and collected 71 grids of clay targets, of which 27 were not grazed and 44 were grazed. Of these, 26 met our criteria for experimentally paired grids (13 pairs of grazed and ungrazed grids). The proportion of broken clay targets was significantly larger within grazed grids than within the paired ungrazed grids $\left(\mu_{\mathrm{t} \text {-test }}=3.92,90 \%\right.$ lower confidence interval $=1.80$, degrees of freedom $=12$; Fig. 2A). Upper confidence interval is not presented here because the test was one-tailed. Experimentally paired grids that were grazed had higher trampling rates than ungrazed grids ( $4 \%$ of clay targets were trampled versus $0 \%$ per nesting cycle, respectively).

\section{Grazing and cattle density}

For all grids $(N=71)$, experimental and non-experimental combined, all measures of cattle were significantly associated with trampling rates. Whether a site was grazed was a positive and significant predictor of rates of clay targets trampled compared to the null model $\left(w_{i}=0.70\right)$. Trampling rates were $7 \%$ grazed versus $2 \%$ ungrazed per nesting cycle. The percent difference in trampling between grazed and ungrazed grids in both analyses was similar to that in experimentally paired grids, approximately $4 \%-5 \%$. Stocking density was significantly associated with rates of clay targets trampled but received low weight $\left(w_{i}=0.22\right.$; see Table 2 for model comparisons and Table 3 for parameter estimates and confidence intervals; Fig. 2B). The average number of cattle counted at each grid was a parsimonious model of rates of trampled clay targets with significant effects; however we excluded this model from comparison calculations because other cattle metrics are more practicable management targets.
Fig. 2. (A) Difference between proportions of clay targets broken from paired grids that were grazed and ungrazed in adjacent enclosures. (B) Proportion of clay targets broken in grazed and ungrazed enclosures using non-experimental sampling (i.e. using all grids sampled) and 90\% confidence intervals (gray vertical lines). For all plots, data are shown in blue, model predicted means are shown as black lines. We converted model outputs to proportions for generalized interpretation.

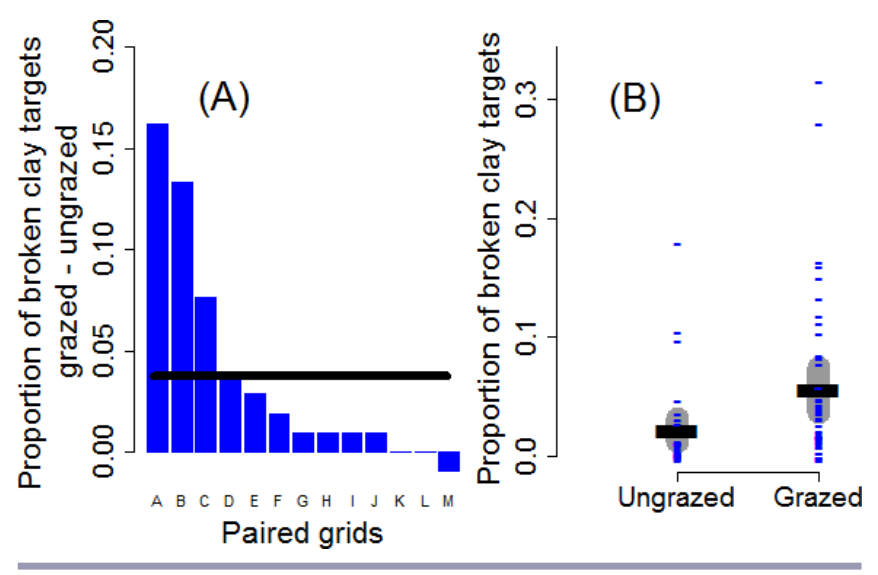

\section{Infrastructure}

For the subset of grids that were located within grazed enclosures $(N=44)$, the most parsimonious model predicted that rates of trampled clay targets were inversely correlated with distance to supplemental trough. The model including distance to trough had more weight $\left(w_{i}=0.59\right)$ when compared with the null model $\left(w_{i}\right.$ $=0.41$ ), but after model averaging, this explanatory variable was no longer significant because $90 \%$ confidence intervals include zero (Tables 2 and 3). Distance to fence and forest, and stocking density were uninformative covariates in all models in which they were included, because $\Delta \mathrm{AIC}_{\mathrm{c}}$ values were $>2.0$ from the most similar model not including these covariates; they and were therefore deemed unimportant (Burnham and Anderson 2002, Arnold 2010) and were excluded from subsequent analysis. 


\section{Simulations}

Averaging all sites, the probability of quasi-extinction at time step 50 was much smaller in ungrazed scenarios (mean difference in the proportion of sites that went extinct $=-0.41$;, Fig. 3 ). Intrinsic growth rate (r) was larger in ungrazed scenarios (mean difference $=0.048$ ). Median abundance at time step 50 was larger in ungrazed scenarios (mean difference $=213.7$ males). Quasi-extinction probability appears to have an inverse relationship with initial abundance (Fig. 3). Kissimmee Prairie Preserve State Park was the only site that had similar quasi-extinction rates regardless of grazing management scenarios, probably because of large initial abundances when compared to other sites (Fig. 3); however, median abundance at time step 50 and intrinsic growth rates largely differed and were smaller in grazed grids (Appendix 2).

Fig. 3. Barplots showing simulated quasi-extinction rates at each aggregation in grazed and ungrazed grids with respect to percent carrying capacity for initial abundance $(\% \mathrm{~K})$. Each plot is an aggregation including Kissimmee Prairie Preserve State Park (KPPSP), Three Lakes Wildlife Management Area (TLWMA), Cutrale Farms, and Avon Park Air Force Range including Bravo, Delta/OQ, and Echo.

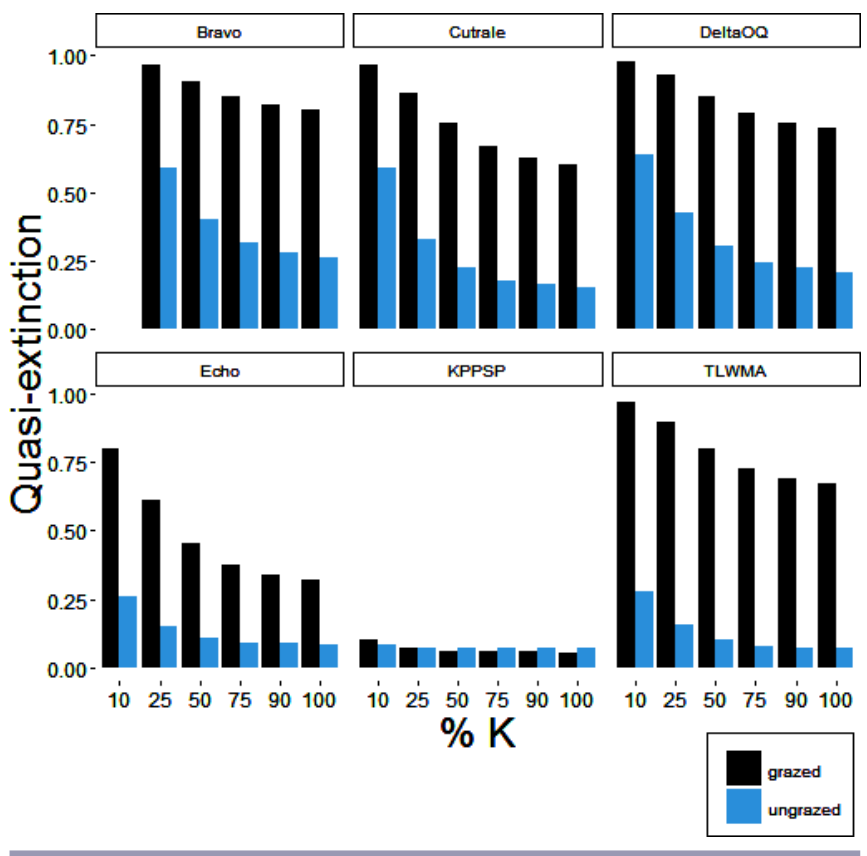

\section{DISCUSSION}

Overall, our study demonstrates that trampling rates on artificial nests are influenced by grazing status. The magnitude of effects from trampling are likely to be biologically significant given known demographic rates of Florida Grasshopper Sparrows. Intrinsic growth rates, quasi-extinction probabilities, and median abundances were strongly affected by grazing, suggesting that trampling could have played a role in historical population declines by Florida Grasshopper Sparrows at grazed sites.

Quasi-extinction rates tended to decrease with initial population size (Fig. 3) at all sites except Kissimmee Prairie Preserve State Park, which resulted from large initial abundances and a large carrying capacity. This estimate for Kissimmee Prairie Preserve State Park may be overly optimistic given that Perkins et al. (2008) specified higher demographic rates at Kissimmee Prairie Preserve State Park than other sites, and the monitored population has since declined below population sizes simulated here. Furthermore, median abundance and intrinsic growth rates diverged between management scenarios (Appendix 2).

Magnitude of the effect from grazing initially appears small, but multiplies over several nesting attempts and across multiple breeding seasons, resulting in large divergences population viability. A relatively long breeding season in Florida allows for approximately four to five nesting attempts (Perkins et al. 2003). Smaller population-level effects would be expected in more northerly populations of other subspecies with shorter breeding seasons and fewer nesting attempts. Other studies have found small direct effects of nest destruction by cattle, but these effects were deemed unimportant in Canada (e.g. Bleho et al. 2014). Simulations, as applied here, allowed us to directly assess projected population-level effects to fully understand relative implications of management.

Trampling rates were spatially homogenous within enclosures and with respect to troughs, fences, and forests. Although distance to fence, forest, and trough did not induce spatial heterogeneity on trampling rates, several clay target grids located near troughs were trampled at rates as high as $30 \%$ whereas grids $>2.1 \mathrm{~km}$ from troughs were trampled at rates $<10 \%$, suggesting that troughs located near important habitat could pose substantially higher risk to nests and further research is warranted given our marginally insignificant results and moderate sample sizes. Our study took place on public lands with relatively low stocking densities; however, future conservation efforts plan to include private lands that could have much higher stocking densities (e.g., Everglades Headwaters National Wildlife Refuge; Perkins et al. 2008). Our model including cattle counts as a covariate was parsimonious (Table 2); however, we excluded cattle counts from further interpretation because management using cattle counts would be difficult to implement, and stocking density models performed poorly compared to grazing status. Improved estimates of stocking rates may allow managers to more accurately estimate influence of cattle density on trampling rates in Florida Grasshopper Sparrow habitat.

Competing management objectives may have incompatible management strategies when considering endangered species, military training, wildlife preserves, recreation, and supporting a local ranching culture and economy. We highlight the importance of avoiding grazing in occupied Florida Grasshopper Sparrow habitat during the peak of the breeding season, which would nearly eliminate trampling risk to nests and potentially shift population trajectories.

Our study, which combines biologically relevant field techniques with simulations, demonstrates that low-magnitude trampling rates can have substantial impacts on population viability. Grazing should be considered cautiously in future management of the Florida Grasshopper Sparrow, and the potential effects from cattle extend beyond trampling (e.g. Pranty 2000, Tucker et al. 2010b). Managers wanting to graze cattle on ground-nesting bird habitat during the breeding season should empirically demonstrate demographic benefits that offset the risk from trampling. 
Comparisons between the risk of trampling in control (ungrazed) and grazed grids combined with population viability analysis may be a useful technique to assess responses from ground-nesting birds to trampling. Our study informs management for the Florida Grasshopper Sparrow, and our methods can be used to conserve biodiversity.

Responses to this article can be read online at: http://www.ace-eco.org/issues/responses.php/838

\section{Acknowledgments:}

The U.S. Fish and Wildlife Service funded this research under grant agreement \#40181 AG079. This research was undertaken as part of long-term project on Florida Grasshopper Sparrows funded by the Department of Defense. We thank Paul Ebersbach, Mark Fredlake, Clarence Morgan, and Sandra Sneckenberger for logistical support. Angela Johnson assisted with field work. We thank Allison Moody, the Florida Grasshopper Sparrow Working Group, and two anonymous reviewers for providing comments that greatly improved this manuscript.

\section{LITERATURE CITED}

Allen, C. R., S. Demarais, and R. S. Lutz. 1994. Red imported fire ant impact on wildlife - an overview. Texas Journal of Science 46:51-59.

Arnold, T. W. 2010. Uninformative parameters and model selection using Akaike's information criterion. Journal of Wildlife Management 74:1175-1178. http://dx.doi.org/10.2193/2009-367

Bailey, D. W., J. E. Gross, E. A. Laca, L. R. Rittenhouse, M. B. Coughenour, D. M. Swift, and P. L. Sims. 1996. Mechanisms that result in large herbivore grazing distribution patterns. Journal of Range Management 49:386-400. http://dx.doi.org/10.2307/4002919

Bareiss, L. J., P. Schulz, and F. S. Guthery. 1986. Effects of shortduration and continuous grazing on bobwhite and wild turkey nesting. Journal of Range Management 39:259-260. http://dx.doi. org/10.2307/3899063

Beintema, A. J., and G. J. D. M Muskens. 1987. Nesting success of birds breeding in Dutch agricultural grasslands. Journal of Applied Ecology 24:743-758. http://dx.doi.org/10.2307/2403978

Bleho, B. I., N. Koper, and C. S. Machtans. 2014. Direct effects of cattle on grassland birds in Canada. Conservation Biology 28:724-734. http://dx.doi.org/10.1111/cobi.12259

Bock C. E., J. H. Bock, W. R. Kenney, and V. M. Hawthorne. 1984. Responses of birds, rodents, and vegetation to livestock exclosure in a semidesert grassland site. Journal of Range Management 37:240-242. http://dx.doi.org/10.2307/3899146

Bock, C. E., and B. Webb. 1984. Birds as grazing indicator species in southeastern Arizona. Journal of Wildlife Management 48:1045-1049. http://dx.doi.org/10.2307/3801466

Brennan, L. A., and W. P. Kuvlesky, Jr. 2005. Invited paper: North American grassland birds: an unfolding conservation crisis? Journal of Wildlife Management 69:1-13. http://dx.doi. org/10.2193/0022-541X(2005)069<0001:NAGBAU>2.0.CO;2
Bridges, E. L. 2006. Landscape ecology of Florida dry prairie in the Kissimmee River region. Pages 14-42 in R. Noss, editor. Land of fire and water: the Florida dry prairie ecosystem. Proceedings of the Florida Dry Prairie Conference, October 5-7, 2004, Chateau Elan, Sebring, Florida. E.O. Painter Printing Company, DeLeon Springs, Florida, USA. [online] URL: http://www.ces. fau.edu/fdpc/proceedings.php

Burnham, K. P., and D. R. Anderson, editors. 2002. Model selection and multimodel inference. Springer, New York, New York, USA. http://dx.doi.org/10.1007/b97636

Delany, M. F., and S. B. Linda. 1998. Characteristics of Florida Grasshopper Sparrow nests. Wilson Bulletin 110:136-139.

Delany, M. F., M. B. Shumar, M. E. McDermott, P. S. Kubilis, J. L. Hatchitt, and R. G. Rivero. 2007. Florida Grasshopper Sparrow distribution, abundance, and habitat availability. Southeastern Naturalist 6:15-26. http://dx.doi.org/10.1656/1528-7092 (2007)6[15:FGSDAA]2.0.CO;2

Green, R. E. 1988. Effects of environmental factors on the timing and success of breeding of common snipe Gallinago gallinago (Aves: Scolopacidae). Journal of Applied Ecology 25:79-93. http:// dx.doi.org/10.2307/2403611

Griebel, R. L., S. L. Winter, and A. A. Steuter. 1998. Grassland birds and habitat structure in sandhills prairie managed using cattle or bison plus fire. Great Plains Research 8:255-268.

Henry, V. G. 1969. Predation on dummy nests of ground-nesting birds in Southern Appalachians. Journal of Wildlife Management 33:169-172. http://dx.doi.org/10.2307/3799666

Hovick, T. J., J. R. Miller, R. R. Koford, D. M. Engle, and D. M. Debinski. 2011. Postfledging survival of Grasshopper Sparrows in grasslands managed with fire and grazing. Condor 113:429-437. http://dx.doi.org/10.1525/cond.2011.100135

Hovick, T. J., J. R. Miller, S. J. Dinsmore, D. M. Engle, D. M. Debinski, and S. D. Fuhlendorf. 2012. Effects of fire and grazing on grasshopper sparrow nest survival. Journal of Wildlife Management 76:19-27. http://dx.doi.org/10.1002/jwmg.243

Jensen, H. P., D. Rollins, and R. L. Gillen. 1990. Effects of cattle stock density on trampling loss of simulated ground nests. Wildlife Society Bulletin 18:71-74.

Kantrud, H. A., and R. L. Kologiski. 1982. Effects of soils and grazing on breeding birds of uncultivated upland grasslands of the northern Great Plains. Wildlife Research Report 15. U.S. Fish and Wildlife Service, Washington, D.C., USA.

Koerth, B. H., W. M. Webb, F. C. Bryant, and F. S. Guthery. 1983. Cattle trampling of simulated ground nests under short duration and continuous grazing. Journal of Range Management 36:385-386. http://dx.doi.org/10.2307/3898494

Lesnoff, M., and R. Lancelot. 2012. aod: Analysis of overdispersed data. R package version 1.3. [online] URL: http:// cran.r-project.org/package $=$ aod

Liker, A., and T. Székely. 1997. The impact of grazing and road use on hatching success of lapwings (Vanellus vanellus). Acta Zoologica Academiae Scientiarum Hungaricae 43:85-92. 
McNair, D. B. 1986. Clutch information for the Florida Grasshopper Sparrow from oological collections. Florida Field Naturalist 14:48-49.

Nack, J. L., and C. A. Ribic. 2005. Apparent predation by cattle at grassland bird nests. Wilson Bulletin 117:56-62. http://dx.doi. org/10.1676/04-056

Nakagawa, S., and I. C. Cuthill. 2007. Effect size, confidence interval and statistical significance: a practical guide for biologists. Biological Reviews 82:591-605. http://dx.doi. org/10.1111/j.1469-185X.2007.00027.X

Noss, R. F. 2013. Forgotten grasslands of the South: natural history and conservation. Island Press, Washington, D.C., USA. http:// dx.doi.org/10.5822/978-1-61091-225-9

Paine, L., D. J. Undersander, D. W. Sample, G. A. Bartelt, and T. A. Schatteman. 1997. Technical note: comparison of simulated ground nest types for grazing/trampling research. Journal of Range Management 50:231-233. http://dx.doi.org/10.2307/4003720

Pakanen, V.-M., A. Luukkonen, and K. Koivula. 2011. Nest predation and trampling as management risks in grazed coastal meadows. Biodiversity and Conservation 20:2057-2073. http://dx. doi.org/10.1007/s10531-011-0075-3

Pavel, V. 2004. The impact of grazing animals on nesting success of grassland passerines in farmland and natural habitats: a field experiment. Folia Zoologica Praha 53:171-178.

Perkins, D. W., and P. D. Vickery. 2001. Annual survival of an endangered passerine, the Florida Grasshopper Sparrow. Wilson Bulletin 113:211-216. http://dx.doi.org/10.1676/0043-5643(2001) 113[0211:ASOAEP]2.0.CO;2

Perkins, D. W., P. D. Vickery, and W. G. Shriver. 2003. Spatial dynamics of source-sink habitats: effects on rare grassland birds. Journal of Wildlife Management 67:588-599. http://dx.doi. org/10.2307/3802716

Perkins, D. W., P. D. Vickery, and W. G. Shriver. 2008. Population viability analysis of the Florida Grasshopper Sparrow (Ammodramus savannarum floridanus): testing recovery goals and managment options. Auk 125:167-177. http://dx.doi.org/10.1525/ auk.2008.125.1.167

Perkins, D. W., W. G. Shriver, and P. D. Vickery. 2009. The effects of fire on the breeding ecology of Florida Grasshopper Sparrows (Ammodramus savannarum floridanus) and Bachman's Sparrows (Aimophila aestivalis). Florida Field Naturalist 37:121-145.

Peterjohn, B. G., and J. R. Sauer. 1999. Population status of North American grassland birds from the North American Breeding Bird Survey. 1966-1996. Studies in Avian Biology 19:27-44.

Pranty, B. 2000. Three sources of Florida Grasshopper Sparrow mortality. Florida Field Naturalist 28:27-29.

Pranty, B., and J. W. Tucker. 2006. Ecology and management of the Florida Grasshopper Sparrow. Pages 188-200 in R. Noss, editor. Land of fire and water: the Florida dry prairie ecosystem. Proceedings of the Florida Dry Prairie Conference, October 5-7, 2004, Chateau Elan, Sebring, Florida. E.O. Painter Printing Company, DeLeon Springs, Florida, USA. [online] URL: http:// www.ces.fau.edu/fdpc/proceedings.php
Rader, M. J., T. W. Teinert, L. A. Brennan, F. Hernandez, N. J. Silvy, and X. B. Wu. 2007. Identifying predators and nest fates of bobwhites in southern Texas. Journal of Wildlife Management 71:1626-1630. http://dx.doi.org/10.2193/2006-185

Rahmig, C. J., W. E. Jensen, and K. A. With. 2009. Grassland bird responses to land management in the largest remaining tallgrass prairie. Conservation Biology 23:420-432. http://dx.doi. org/10.1111/j.1523-1739.2008.01118.x

Renfrew, R. B., C. A. Ribic, and J. L. Nack. 2005. Edge avoidance by nesting grassland birds: a futile strategy in a fragmented landscape. Auk 122:618-636. http://dx.doi.org/10.1642/0004-8038 (2005)122[0618:EABNGB]2.0.CO;2

Rummell, R. S. 1957. Beef cattle production and range practices in south Florida. Journal of Range Management 10:71-78. http:// dx.doi.org/10.2307/3894592

Shochat, E., M. A. Patten, D. W. Morris, D. L. Reinking, D. H. Wolfe, and S. K. Sherrod. 2005. Ecological traps in isodars: effects of tallgrass prairie management on bird nest success. Oikos 111:159-169. http://dx.doi.org/10.1111/j.0030-1299.2005.13907. $\mathrm{x}$

Shriver, W. G., and P. D. Vickery. 1999. Aerial assessment of potential Florida Grasshopper Sparrow habitat conservation in a fragmented landscape. Florida Field Naturalist 27:1-9.

Sutter, B., and G. Ritchison. 2005. Effects of grazing on vegetation structure, prey availability, and reproductive success of Grasshopper Sparrows. Journal of Field Ornithology 76:345-351. http://dx.doi.org/10.1648/0273-8570-76.4.345

Tschinkel, W. R. 1988. Distribution of the fire ants Solenopsis invicta and S. geminata (Hymenoptera: Formicidae) in northern Florida in relation to habitat and disturbance. Annals of the Entomological Society of America 81:76-81. http://dx.doi. org/10.1093/aesa/81.1.76

Tschinkel, W. R. 1993. The fire ant (Solenopsis invicta): still unvanquished. Pages 121-136 in B. N. McKnight, editor. Biological pollution: the control and impact of invasive exotic species. Proceedings of a symposium held at Indianapolis, Indiana, USA, 25-26 October 1991. Indiana Academy of Science, Indianapolis, Indiana, USA.

Tucker, J. W., Jr., G. R. Schrott, M. F. Delany, S. L. Glass, C. L. Hannon, P. Miller, and R. Bowman. 2010a. Metapopulation structure, population trends, and status of Florida Grasshopper Sparrows. Journal of Field Ornithology 81:267-277. http://dx.doi. org/10.1111/j.1557-9263.2010.00282.x

Tucker, J. W., Jr., G. R. Schrott, and R. Bowman. 2010b. Fire ants, cattle grazing, and the endangered Florida Grasshopper Sparrow. Southeastern Naturalist 9:237-250. http://dx.doi.org/10.1656/058.009.0203

U. S. Fish and Wildlife Service. 1986. Endangered and threatened wildlife and plants; determination of endangered status for the Florida Grasshopper Sparrow: final rule. Federal Register 51:27492-27495.

U.S. Department of Agriculture. 2015. Cattle \& beef. Economic Research Service, U.S. Department of Agriculture, Washington, D.C., USA. [online] URL: http://www.ers.usda.gov/topics/ animal-products/cattle-beef/statistics-information.aspx 
U.S. Department of Interior. 2015. Fact sheet on the BLM's management of livestock grazing. Bureau of Land Management, U.S. Department of Interior, Washington, D.C., USA. [online] URL: http:/www.blm.gov/wo/st/en/prog/grazing.html

Usman, H. 1994. Cattle trampling and soil compaction effects on soil properties of a northeastern Nigerian sandy loam. Arid Land Research and Management. 8:69-75. http://dx.doi.

org/10.1080/15324989309381379

Vickery, P. D. 1996. Grasshopper Sparrow (Ammodramus savannarum). The Birds of North America Online. Cornell Lab of Ornithology, Ithaca, New York, USA. http://bna.birds.cornell. edu/bna/species/239

With, K. A., A. W. King, and W. E. Jensen. 2008. Remaining large grasslands may not be sufficient to prevent grassland bird declines. Biological Conservation 141:3152-3167. http://dx.doi.org/10.1016/ j.biocon.2008.09.025 
Appendix 1. Variables (SDs) used in population viability analyses.

\begin{tabular}{llllrr}
\hline \hline Site & Adult & survival & Juvenile survival & Nest success & \multicolumn{2}{l}{$\begin{array}{l}\text { Nest } \\
\text { attempts }\end{array}$} & Young \\
\hline Bravo & $0.51(0.09)$ & $0.351(0.22)$ & $0.203(0.04)$ & 4.774 & 3.2 \\
Cutrale & $0.51(0.09)$ & $0.351(0.22)$ & $0.203(0.04)$ & 4.774 & 3.2 \\
DeltaOQ & $0.48(0.09)$ & $0.351(0.22)$ & $0.203(0.04)$ & 4.774 & 3.2 \\
Echo & $0.51(0.09)$ & $0.351(0.22)$ & $0.203(0.04)$ & 4.774 & 3.2 \\
TLWMA & $0.53(0.08)$ & $0.351(0.22)$ & $0.151(0.04)$ & 5.363 & 3.2 \\
KPPSP & $0.51(0.09)$ & $0.351(0.22)$ & $0.26(0.03)$ & 4.24 & 3.2 \\
\hline
\end{tabular}


Appendix 2. Population viability analysis results for quasi-extinction at time step 50 , intrinsic growth rate, and median abundance at time step 50. Simulations were run for six aggregations.

\begin{tabular}{|c|c|c|c|c|c|c|c|c|c|}
\hline \multirow[t]{2}{*}{ Aggregation } & \multirow[t]{2}{*}{ K } & \multirow[t]{2}{*}{$\% \mathrm{~K}$} & \multirow[t]{2}{*}{ Inits } & \multicolumn{2}{|c|}{ Quasi-extinction } & \multicolumn{2}{|c|}{ Median abundance } & \multicolumn{2}{|c|}{ Intrinsic growth rate } \\
\hline & & & & Ungrazed & Grazed & Ungrazed & Grazed & Ungrazed & Grazed \\
\hline \multirow[t]{6}{*}{ Bravo } & 30 & 10 & 3 & NA & NA & NA & NA & NA & NA \\
\hline & & 25 & 8 & 0.59 & 0.97 & 0 & 0 & 0.012 & -0.019 \\
\hline & & 50 & 15 & 0.40 & 0.90 & 18 & 0 & 0.001 & -0.037 \\
\hline & & 75 & 22 & 0.31 & 0.85 & 30 & 0 & -0.005 & -0.043 \\
\hline & & 90 & 27 & 0.28 & 0.82 & 30 & 0 & -0.009 & -0.046 \\
\hline & & 100 & 30 & 0.26 & 0.80 & 30 & 0 & -0.010 & -0.047 \\
\hline \multirow[t]{6}{*}{ Cutrale } & 78 & 10 & 8 & 0.59 & 0.97 & 0 & 0 & 0.018 & -0.019 \\
\hline & & 25 & 20 & 0.33 & 0.86 & 28 & 0 & 0.006 & -0.041 \\
\hline & & 50 & 39 & 0.22 & 0.75 & 57 & 0 & -0.002 & -0.049 \\
\hline & & 75 & 58 & 0.18 & 0.67 & 78 & 0 & -0.007 & -0.052 \\
\hline & & 90 & 70 & 0.16 & 0.63 & 78 & 0 & -0.010 & -0.053 \\
\hline & & 100 & 78 & 0.15 & 0.60 & 78 & 0 & -0.011 & -0.054 \\
\hline \multirow[t]{6}{*}{ DeltaOQ } & 109 & 10 & 11 & 0.63 & 0.98 & 0 & 0 & 0.003 & -0.040 \\
\hline & & 25 & 27 & 0.43 & 0.93 & 12 & 0 & -0.008 & -0.060 \\
\hline & & 50 & 54 & 0.30 & 0.85 & 28 & 0 & -0.014 & -0.068 \\
\hline & & 75 & 82 & 0.25 & 0.79 & 43 & 0 & -0.018 & -0.071 \\
\hline & & 90 & 98 & 0.22 & 0.76 & 51 & 0 & -0.020 & -0.072 \\
\hline & & 100 & 109 & 0.21 & 0.74 & 58 & 0 & -0.021 & -0.073 \\
\hline \multirow[t]{6}{*}{ Echo } & 303 & 10 & 30 & 0.26 & 0.80 & 43 & 0 & 0.009 & -0.046 \\
\hline & & 25 & 76 & 0.15 & 0.61 & 113 & 0 & 0.002 & -0.053 \\
\hline & & 50 & 152 & 0.11 & 0.46 & 233.5 & 7 & -0.004 & -0.056 \\
\hline & & 75 & 227 & 0.09 & 0.38 & 303 & 11 & -0.009 & -0.058 \\
\hline & & 90 & 273 & 0.09 & 0.34 & 303 & 13 & -0.011 & -0.059 \\
\hline & & 100 & 303 & 0.08 & 0.32 & 303 & 15 & -0.012 & -0.059 \\
\hline \multirow[t]{6}{*}{ TLWMA } & 1250 & 10 & 125 & 0.28 & 0.97 & 22 & 0 & -0.033 & -0.113 \\
\hline & & 25 & 312 & 0.16 & 0.90 & 53 & 0 & -0.036 & -0.117 \\
\hline & & 50 & 625 & 0.10 & 0.80 & 107 & 0 & -0.037 & -0.119 \\
\hline & & 75 & 938 & 0.08 & 0.73 & 159 & 0 & -0.039 & -0.121 \\
\hline & & 90 & 1125 & 0.07 & 0.69 & 190 & 0 & -0.039 & -0.122 \\
\hline & & 100 & 1250 & 0.07 & 0.67 & 213.5 & 0 & -0.039 & -0.122 \\
\hline \multirow[t]{6}{*}{ KPPSP } & 1852 & 10 & 185 & 0.08 & 0.11 & 1852 & 176 & 0.034 & -0.002 \\
\hline & & 25 & 463 & 0.07 & 0.07 & 1852 & 445 & 0.021 & -0.006 \\
\hline & & 50 & 926 & 0.07 & 0.06 & 1852 & 908 & 0.010 & -0.010 \\
\hline & & 75 & 1389 & 0.07 & 0.06 & 1852 & 1327 & 0.002 & -0.014 \\
\hline & & 90 & 1667 & 0.07 & 0.06 & 1852 & 1614 & -0.001 & -0.015 \\
\hline & & 100 & 1852 & 0.07 & 0.06 & 1852 & 1779 & -0.003 & -0.016 \\
\hline
\end{tabular}

